\title{
Effectiveness of Multicultural-based Comic to Improve Learning Achievement and Tolerance Characters in Elementary School
}

\author{
Albi Anggito*, E. Kus Eddy Sartono, Ali Mustadi, Nada Savitri Nawangsari, \\ Astri Widyasari \\ Faculty of Education, Universitas Negeri Yogyakarta, Indonesia \\ ${ }^{*}$ Corresponding author. Email: albianggito.2020@ student.uny.ac.id

\begin{abstract}
Student success in the 2013 curriculum in elementary school seeks to improve student learning achievement and instill character values derived from Indonesian culture. Problems in the field show that social learning achievement is relatively low in social learning material. Teachers have difficulty developing media to instill a character of tolerance that can be integrated into the material diversity of Indonesian culture. This research aims to determine the effectiveness of CITA (Cerita Indonesia Kita) comic media on social science learning achievement and the character tolerance of $4^{\text {th }}$ grade elementary school students. The type of research used is quasi-experimentation with pre-test post-test group design. The subjects of this study are students and teachers of $4^{\text {th }}$ grade Public Elementary School P., Bantul, Yogyakarta Special Region. The instruments used are the tolerance character scale and the social learning achievement test. Data analysis uses independent sample t-test and paired sample t-test at significance level 0.05 . The results showed that the multicultural-based CITA comic medium effectively improved social learning achievement and the character tolerance of $4^{\text {th }}$ grade elementary school students. The effectiveness of comics can be seen from the independent sample t-test and paired sample t-test, which shows a significance value of 0.000 .
\end{abstract}

Keywords: Character tolerance, comic, Learning achievement

\section{INTRODUCTION}

Learning activities in elementary schools should essentially begin to implement multicultural education to students. Multicultural education facilitates quality interaction between individuals with a variety of ideas and perspectives to choose the proper steps in solving problems in a very diverse social life [1]. Multicultural education is a concept that recognizes the importance of diversity in student life, establishes equality, and upholds social justice in education. The presence of multicultural education has an important goal to reduce cases of intolerance to create an atmosphere of mutual respect. Thus, teachers need to carry out multiculturalbased learning to foster the character of student tolerance [2].
The character of tolerance becomes very important because of the very diverse environmental conditions of students. Patience will get used to not being selfish and realize that the good thing for yourself is not necessarily good for others [3]. In a child, tolerance is concerned with children's developing awareness of relationships with others and accepting different appearances and behavior between self and others [4]. Especially considering that Indonesia is a very multicultural country, tolerance is necessary to be instilled early on.

There are at least 11 indicators of the character of tolerance, namely: caring, inaction, love, respect for each other, respecting the differences of others, respecting yourself, respecting the kindness of others, being open, receptive, comfort in life, and comfort with others [5]. The ingrained attitude of tolerance in students will make him wiser in meeting a difference in 
his environment. This creates awareness of the importance of the learning process in schools to instill character values derived from the nation's cultural values.

Meanwhile, the success of the learning process will be more ideal when not only successfully instilling character values but also being able to get good learning achievement. Learning achievement is obtained from learning activities, or the results of effort, practice, and experience carried out by someone who is inseparable from external factors of students [6]. Learning achievement is very important because it can be used as an evaluation in learning and as one of the standards of learning success. Learning achievement refers more to learning outcomes that are cognitive in nature, so it is often used as an indicator of a student's intelligence.

Learning media becomes one way that can be used to improve student learning achievement and tolerance character. Media can be used as a tool to help the learning process and function to clarify the meaning of the message conveyed, making it easier to achieve the goal better and perfectly [7]. In addition, the use of media can also shorten effectiveness and efficiency in achieving learning goals [8]. The use of media will make learning more interesting so as to foster students' learning interests.

Based on the results of interviews with the guardians of grade $4^{\text {th }}$ elementary school in Jejeran, Pleret Subdistrict, Bantul Regency, Yogyakarta obtained information that the value of subjects in thematic learning is still low is social learning, especially in the material diversity of Indonesian culture, fundamental difficulties related to the vast scope of material and rote nature. An impact of this, students become lazy to learn it, but the re-grades are below the minimum completion. It is also in line with the student's recognition that the boring subject is social science because the material is very much and lazy to memorize it.

The data is strengthened by conducting learning observations and literature studies that show students are more interested in the media used in learning but media that accommodate the diversity of Indonesian culture. In addition, media that try to instill the character of tolerance is also minimal, only in the form of posters and images affixed to the school's walls. The press that teachers have used in teaching the diversity of Indonesian culture is through PowerPoint media. However, teachers realize that they often experience limited time and make learning media continuous in learning.

Based on the above problems, it is crucial to involve more exciting and varied learning media so that students do not get bored in learning. One of the potential ways to overcome this problem is to use comics. The selection of comics as a learning medium has a variety of learning media. Through educational comics, the learning content that will be delivered with a clear and exciting storyline will make the content last longer in children's memory [9]. The use of educational comic media in learning can expand knowledge, increase potential, provide equal learning opportunities, and improve the student discussion climate [10]. No less important is that comics can also be utilized in the teaching of character education in elementary schools [11].

Comics become one of the visual media that can be used by teachers in order to increase students' reading interest and interpretation of reading text [12]. This is because comics are not a foreign thing for students, because various types and titles of comics have been widely circulated. The use of comics is also expected to support the learning process because it can improve student literacy [13]. Comics have elements in the form of images / illustrations, so as to make students interested and easier to understand the story [14], [15]. In addition, comics are also able to bring readers into the world they read and allow them to blend in with characters that seem real to the reader [16].

One of the developments of comic media that has been tested worthy of learning is CITA (Cerita Indonesia Kita) comics. This comic can be used as an alternative in problem-solving that has been described so that this research will aim to test the effectiveness of CITA Comics on social learning achievement and the character of tolerance of grade four elementary school students. The purpose in this study is to find out the effectiveness of CITA comics in improving social science learning achievement and the character of tolerance of grade four elementary students.

\section{RESEARCH METHODS}

\subsection{Data}

Data collection uses tests and psychological scale. Tests are used to measure a student's social science learning achievement, while psychological scales measure and increase a student's tolerance character. Before being given to students, the student's tolerance character and test questions are first validated by experts. The data that has been obtained is then tabulated and converted into qualitative data with reference to conversion guidelines. Furthermore, the data was analyzed to determine the effectiveness of CITA Comics in improving social science learning achievement and tolerance character with normality tests, homogeneity tests, independent sample t-test, and paired sample t-test with a significance level of 0.05 . 


\subsection{Method}

Material experts have validated CITA comics to be used in experimental research, media experts and have been piloted to students and have been declared fit for use and tried to students. Therefore, the research that will be used is quasi-experimentation with pre-test posttest group design. Here's an image of the operational field trial design.

Time
\begin{tabular}{|l|l|l|l|}
\hline Select-control group & Pre-test & No treatment & Post-test \\
\hline $\begin{array}{l}\text { Select experimental } \\
\text { group }\end{array}$ & Pre-test & $\begin{array}{l}\text { Experimental } \\
\text { treatment }\end{array}$ & Post-test \\
\hline
\end{tabular}

Figure 1. Pre-test \& post-test design [17]

The steps in quasi-experimental research can be seen in the following order.

1) Specify classes for experimental classes and control classes with records must be qualified with no significant differences

2) Pre-test at the beginning of learning to find out social science learning achievement and character tolerance in experimental classes and control classes.

3) Teachers in experimental class groups utilize CITA comics in the implementation of learning

4) Teachers in the control class group conducted learning as usual using power point media.

5) Teachers and researchers should pay attention to the learning process by using observation sheets.

6) After learning is complete, do a test post to find out the learning achievement and character tolerance of students in experimental classes and control classes.

7) Input social science learning achievement data and tolerance character both pre-test and post-test data to SPSS 16

8) Data analysis with SPSS16 for normality test, homogeneity test, independent t-test sample, and paired sample t-test against tolerance character data and pre-test post-test data on student science learning achievement.

9) Finally, data analysis with SPSS16 for normality test, homogeneity test, independent t-test sample, and paired sample t-test against tolerance character data and pre-test post-test data on student science learning achievement.

\section{RESULT AND DISCUSSION}

\subsection{Data Result of Tolerance}

Psychological scales about tolerance characters are used to look at the influence of CITA comic use on student tolerance characters. Tolerance character measurements were carried out on the operational field at Elementary School P. with $4^{\text {th }}$ A class as a control group and class $4^{\text {th }} \mathrm{B}$ as an experimental group. Control classes are used as comparison classes and aim to know the difference between clearly being given treatment and classes that are not treated. The treatment was given to the experimental class in the form of a multiculturalbased CITA comic media for social science material in theme 1 "Indahnya Kebersamaan". Furthermore, the data is analyzed through stages, namely independent ttest and paired sample t-test. The following are the results of data collection and analysis from each test.

\subsubsection{Data of Independent Sample T-test Tolerance Character}

After conducting a prerequisite test, namely the normality and homogeneity tests, and declaring normal and homogeneous data distribution, the next step is to conduct an independent sample t-test. This test aims to find out the or absence of an average difference from two unpaired samples. Here is a table of the independent sample t-test for pre-test and post-test data on student tolerance characters.

Table 1. The result of independent sample t-test of character tolerance

\begin{tabular}{|l|l|l|}
\hline Data & Sig. & Result \\
\hline $\begin{array}{l}\text { Pre tolerance character } \\
\text { between control and } \\
\text { experimental classes }\end{array}$ & 0,842 & $\begin{array}{l}\text { There is no } \\
\text { significant } \\
\text { difference }\end{array}$ \\
\hline $\begin{array}{l}\text { Post tolerance character } \\
\text { between control and } \\
\text { experimental classes }\end{array}$ & 0,000 & $\begin{array}{l}\text { There can be a } \\
\text { significant } \\
\text { difference }\end{array}$ \\
\hline
\end{tabular}

Based on Table 1, the pre-experimental results show that the character tolerance between the control class and the experimental class did not significantly differ. Meanwhile, the post-use of comics as a learning medium showed a significant difference in the character's tolerance. Both results showed a difference in outcomes between pre-learning and post-learning using CITA comics. The difference proved that experimental classes that used comic media in learning provided significant changes to students' tolerance of characters. In contrast, control classes that only used PowerPoint media showed no significant differences

\subsubsection{Data of Paired Sample T-test Tolerance Character}

Student tolerance character scale data that has been obtained will be used to analyze the effectiveness of CITA comic media. The effectiveness of media against tolerance characters can be seen from the comparison of tolerance character scores before and after the use of comics. Here is a comparison data on the results of student tolerance character in control classes and experimental classes. 


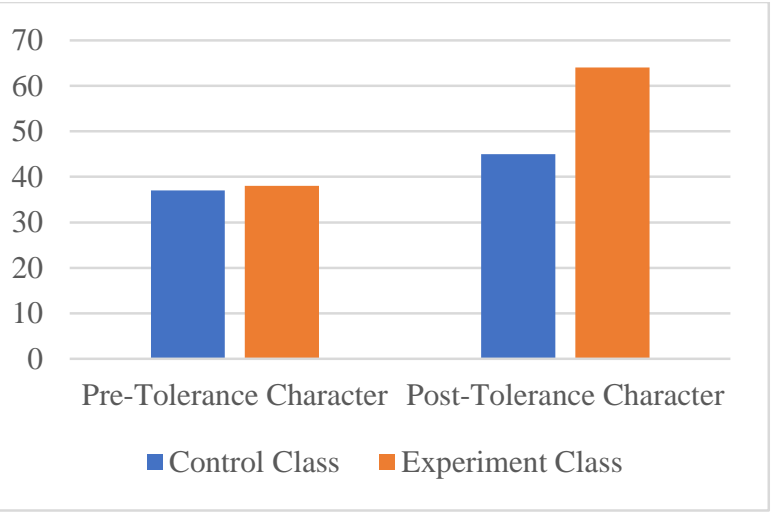

Figure 2. Comparison of the tolerance character of control and experimental classes

Based on Figure 2, it can be seen that the average pre-experimental tolerance character score of the control class and the experimental class are not much different, but the average character score of the post-experiment tolerance of the control class and the experimental class showed very significant differences.

The effectiveness of CITA comic media was tested using a paired sample t-test. Below is the result of the paired sample t-test as follows.

Table 2. The results of paired sample t-test character tolerance data

\begin{tabular}{|c|c|c|c|}
\hline & Data & Sig. & Result \\
\hline Pair 1 & $\begin{array}{l}\text { Pre and post } \\
\text { character tolerance in } \\
\text { the control class }\end{array}$ & 0,065 & $\begin{array}{l}\text { There is no } \\
\text { significant } \\
\text { difference }\end{array}$ \\
\hline Pair 2 & $\begin{array}{l}\text { Pre and post } \\
\text { character tolerance in } \\
\text { the experiment class }\end{array}$ & 0,000 & $\begin{array}{l}\text { There can be a } \\
\text { significant } \\
\text { difference }\end{array}$ \\
\hline
\end{tabular}

Based on Table 2, it was found that the control class did not show any significant differences in the character of tolerance between before and after learning. Meanwhile, the experimental class showed significant differences between the characters before and after learning. Therefore, it can be interpreted that there is no sign of increasing the feeling of tolerance of students in the control class. Still, in the experimental type, there is quite good significance. Thus, it can be concluded that the multicultural-based CITA comic media is effective in improving the character of student tolerance.

\subsection{Result of Social Science Learning Achievement Test}

Social science learning achievement tests are used to find out the extent of success in cognitive implementation in theme material 1, "Indahnya Kebersamaan" This test was conducted as an operational test at Elementary School P. with $4^{\text {th }}$ A class as a control group and $4^{\text {th }} \mathrm{B}$ class as an experimental group. Class control is treated like learning, usually using PowerPoint, while the experimental group uses CITA comic media.

The next step is to perform data analysis using the independent sample t-test and paired sample t-test. Here are the results of calculations and studies from each test.

\subsubsection{Data of Independent Sample T-test on Social Science Learning Achievement}

Independent sample t-test is carried out after the prerequisite test, namely the normality test and homogeneity test, and declared normal and homogeneous data distribution. This test aims to find out the or absence of an average difference from two unpaired samples. Here's a table of t-test sample independent results for student test of social science learning achievement data.

Table 3. The result of the independent sample t-test

\begin{tabular}{|l|l|l|}
\hline Data & Sig. & Result \\
\hline $\begin{array}{l}\text { Pre social science learning } \\
\text { achievement between control } \\
\text { and experimental classes }\end{array}$ & 0,912 & $\begin{array}{l}\text { There is no } \\
\text { significant } \\
\text { difference }\end{array}$ \\
\hline $\begin{array}{l}\text { Post social science learning } \\
\text { achievement between control } \\
\text { and experimental classes }\end{array}$ & 0,000 & $\begin{array}{l}\text { There can be a } \\
\text { significant } \\
\text { difference }\end{array}$ \\
\hline
\end{tabular}

Based on Table 3, the results of pre-experimental test learning achievement between the control class and the experimental class did not have a significant difference. Meanwhile, post-comic test results showed a significant difference in learning achievement. Both results showed a difference in results between prelearning and post-learning using CITA comics. The difference proves that experimental classes that use comic media in learning provide significant changes to students' social learning achievement.

\subsubsection{Data of Paired Sample T-test on Social Science Learning Achievement}

Social science learning achievement data in the material in theme 1 "Indahnya Kebersamaan" is used to analyze the effectiveness of comic media. The efficacy of comic media on learning achievement in social science material can be seen from comparing pre-test and post-test values in learning. The results of the social science learning achievement test to solve problems related to the material diversity of Indonesian culture control class students and experimental classes can be seen from Figure 3.

Based on Figure 3, it can be explained that the average pre-test and post-test scores in control classes and practical classes increase. The increase in the experimental class looks higher in the control class. This shows that CITA comics are effective in improving 
social science learning achievement in the theme material of fourth grade elementary school.

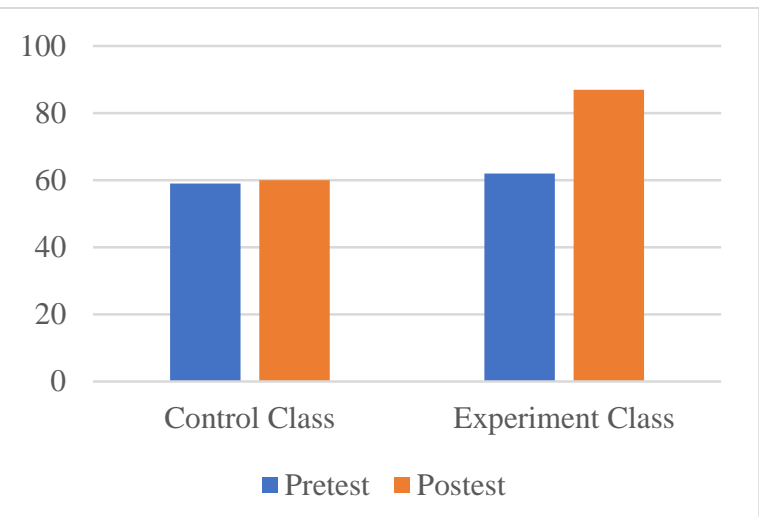

Figure 3. Comparison of pre-test and post-test in control and experiment class

The effectiveness of CITA comic media was tested using a paired sample t-test to compare pre-test and post-test data in control classes and practical classes. Here are the results of paired sample t-test control class and experiment class.

Table 4. The result of paired sample t-test

\begin{tabular}{|l|l|l|l|}
\hline Pair 1 & Data & Sig. & Result \\
\hline $\begin{array}{l}\text { test in the control } \\
\text { lass }\end{array}$ & 0,065 & $\begin{array}{l}\text { There are no } \\
\text { significant } \\
\text { difference }\end{array}$ \\
\hline Pair 2 & $\begin{array}{l}\text { Pre-test and post in } \\
\text { experiment class }\end{array}$ & 0,000 & $\begin{array}{l}\text { There are } \\
\text { significant } \\
\text { difference }\end{array}$ \\
\hline
\end{tabular}

Based on Table 4, it can be concluded that the pretest and post-test values in control classes and experiments differ significantly. The results of the control class had no sign of the student's high social science learning achievement, but in the experimental category, there was tremendous significance. Thus, it can be concluded that the multicultural-based CITA comic media is effective in improving students' social learning achievement

\subsection{Discussion}

Based on the results of research and analysis that have been described above, it was obtained that the purpose of this study is to know the effectiveness of CITA comics on social science learning achievement and the character tolerance of students of $4^{\text {th }}$ class in social science learning content in theme 1 "Indahnya Kebersamaan" has been achieved. This is in accordance with the literature study of the advantages of visual media that can facilitate understanding and strengthen memory and foster students' learning interests [18].
Comics as a visual medium are entertaining and have a function that educates their readers and always has a good moral message.

CITA comics include one of the visual media consisting of text and images (picture stories), so it is easier to understand because it can cause the imagination of students. In line with that, it turns out that reading comics can help visualize the dream of children who can't read [19]. The more students are accustomed to thinking through visuals, such as images contained in comic media, the more accessible students are to understand and remember learning. With pictures, a long and complicated explanation of the text or learning topic can become more accessible for students to understand and remember.

In addition to containing elements of entertainment, comics are also full of meaning and moral messages. However, comics are a medium consisting only of images and text but contain a deep message [20]. In addition to increasing the child's high-level thinking power, educational comics are also able to present learning as well as the sharpening of character values in children. Through comic media can be presented subject matter at the same time can also be instilled character values with pictorial messages that are easily understood by elementary students. When viewed from a positive point of view, reading comics can also help develop a child's imagination [21]. Comics can provide a model that can be used to shape a student's personality.

\section{CONCLUSION}

CITA comics is a multicultural-based media that contains social science material on the theme 1 "Indahnya Kebersamaan" of fourth grade elementary school. The results showed that CITA comics are effective for improving social science learning achievement and character tolerance in fourth grade elementary school. The effectiveness of comics can be seen from the results of the independent sample t-test and paired sample t-test, which shows a significant level of 0.000. Therefore, multicultural-based comics can be used as an alternative medium in improving learning achievement and character tolerance for students in elementary school.

\section{ACKNOWLEDGMENTS}

The authors would like to thank the lecturers in the Elementary Education Study Program, Yogyakarta State University, who have provided guidance and advice. Thanks are also conveyed to the students and guardians of fourth class Public Elementary School, Bantul, Yogyakarta, as the subject of this research. I also thank you to my basic education study program friends who have given their support. 


\section{REFERENCES}

[1] S. Hu, H. Liu, and Q. Huang, The moderating role of social media usage in the relationship among multicultural experiences, cultural intelligence, and individual creativity, Inf. Technol. People, 2017, vol. 30, no. 2, pp. 265-281, doi: 10.1108/ITP-042016-0099.

[2] I. M. D. Atmaja, Membangun toleransi melalui pendidikan multikultural, 2020, J. Pendidik. Kewarganegaraan Undiksha, vol. 8, no. 1, pp. 113-121, [Online]. Available: https://ejournal.undiksha.ac.id/index.php/JJPP/artic le/view/23548/14372.

[3] I. Boghian, Teachers' perspectives on tolerance education: A literature review, J. Innov. Psychol. Educ. Didact., 2016, vol. 20, no. 2, pp. 189-204.

[4] A. Zakin, Hand to hand: teaching tolerance and social justice one child at a time, Child. Educ., 2012, vol. 88, no. 1, pp. 3-13, doi: 10.1080/00094056.2012.643709.

[5] A. Supriyanto and A. Wahyudi, Skala karakter toleransi: konsep dan operasional aspek kedamaian, menghargai perbedaan dan kesadaran individu, Couns. J. Bimbing. dan Konseling, 2017, vol. 7, no. 2, p. 61, doi: 10.25273/counsellia.v7i2.1710.

[6] S. Maesaroh, Peranan Metode Pembelajaran Terhadap Minat dan Prestasi Belajar Pendidikan Agama Islam, J. Kependidikan, vol. 1, no. 359, pp. 150-168, 2013, doi: 10.2307/539575.

[7] C. Kustandi and B. Sutjipto, Media pembelajaran: manual dan digital. Bogor: Ghalia Indonesia, 2013.

[8] A. H. Sanaky, Media pembelajaran interaktifinovatif. Yogyakarta: Kaukaba Dipantara, 2013.

[9] M. Phelan, A Method to the madness: One graphic novelist's process, Horn B. Magazine, vol. 91, no. 6, pp. 40-43, 2015.

[10] M. Pagliaro, Is a picture worth a thousand words? determining the criteria for graphic novels with literary merit, vol. 103, no. 4, pp. 31-45, 2014.

[11] D. K. Murti, Development of educational comics with local wisdom to foster morality of elementary school students: a need analysis, Int. J. Educ. Methodol., vol. 6, no. 2, pp. 337-343, 2020, doi: 10.12973/ijem.6.2.337.

[12] Z. S. Roozafzai, The role of comic reading materials in enhancing the ability to read in EFL, imanager's J. English Lang. Teach., 2012, vol. 2, no. 3, pp. 7-15, doi: 10.26634/jelt.2.3.1959.
[13] B. P. Burke, Using comic books and graphic novels to improve and facilitate community college students' literacy development. India: Indiana University of Pennsylvania, 2012.

[14] B. Lestari and A. Mustadi, Animated video media vs comic on storytelling skills for fifth-graders: Which one is more effective?, J. Educ. Gift. Young Sci., 2020, vol. 8, no. 1, pp. 167-182, doi: $10.17478 /$ jegys.664119.

[15] O. A. Okwilagwe and E. K. Aghotor, Illustrations use as a factor influencing reading comprehension of children's stories among pupils of selected primary schools in Ibadan, Oyo State, Nigeria, Libr. Philos. Pract., 2018, vol. 2018.

[16] M. Kerneža and K. Košir, Comics as a literarydidactic method and their use for reducing gender differences in reading literacy at the primary level of education | Strip kot literarnodidaktična metoda dela in njegova uporaba za zmanjšanje razlik med spoloma v bralni pismenosti na, Cent. Educ. Policy Stud. J., 2016, vol. 6, no. 2, pp. 125-149.

[17] J. W. Creswell, educational research: planning, conducting, and evaluating quantitative and qualitative research (4th ed.), 2012, vol. 148 Boston, MA: Pearson.

[18] A. Arsyad, Media pembelajaran. Jakarta: Raja Grafindo Persada, 2016.

[19] N. M. Nisak, M. B. U. Arifin, and I. M. Fahyuni, Eni Fariyatul Rahmawati, The Development of Comic Formatted Fiqh Textbook for Islamic Elementary School, Eur. J. Educ. Stud., 2021, vol. 8, no. 1, pp. 114-125, doi: 10.46827/ejes.v8i1.3513.

[20] R. Hoffman, Comics in the Omani EFL Classroom: Boosting Student Vocabulary, Reading, and Motivation, 2018, pp. 281-297, doi: 10.1007/978-981-13-0265-7_16.

[21] I. Cimermanová, Using comics with novice EFL readers to develop reading literacy, Procedia - Soc. Behav. Sci., 2015, vol. 174, pp. 2452-2459, doi: 10.1016/j.sbspro.2015.01.916. 